\title{
Building Bridges Between Cultural Studies and Translation Studies: With Reference to the Audiovisual Field*
}

\author{
Juan José Martínez-Sierra \\ Universidad de Murcia
}

\begin{abstract}
This article is based on an intercultural conception of what translating means. First, I illustrate some of the links between cultural studies and translation studies. Translation is defined as an intercultural practice, so the idea that both fields of study converge at a given point is supported. Second, I argue for the figure of the translator as an intercultural expert or mediator, a perception that stems directly from the conception of translation that underlies this paper. Finally, I reflect on the weight that certain cultural notions have in audiovisual translation, focusing on the key role of cultural referents and intertextual allusions. These elements are portrayed as possible restrictions (mainly because of the shared knowledge that is necessary for their comprehension), and their transmission (particularly in the case of cultural referents) is depicted as a consequence of cultural globalization.
\end{abstract}

\footnotetext{
* This research has been conducted as a part of the research project HUM200765518/FILO, Estudio empírico y descriptivo de las normas profesionales de la traducción audiovisual para televisión en España, founded by the Spanish Ministerio de Educación y Ciencia.
} 
116 Building Bridges Between Cultural Studies and Translation Studies

Keywords: audiovisual translation, intercultural communication, mediator, cultural references, intertextuality

\section{Culture and Translation}

There are many definitions of culture. For my purposes, the following will suffice (Samovar and Porter 1997: 12-13):

The deposit of knowledge, experience, beliefs, values, attitudes, meanings, hierarchies, religion, notions of time, roles, spatial relations, concepts of the universe, and material objects and possessions acquired by a group of people in the course of generations through individual and group striving.

This is the definition of culture that I have in mind when I consider the (unavoidable, in my opinion) relationship between this concept and translation practice. As Castro Paniagua (2000: 1) reminds us, Nida (1964) is one of the first authors to deal directly with the cross cultural facet of translation. Nida alerts to "the danger of subjectivity in translating" and to the fact that "it is almost inevitable that translators be affected by their own personal set of values," and he suggests that "they should attempt firmly to avoid any interference from the particular cultural background.”

It could be argued, however, that such an attempt does not seem to be an easy task, since it requires a high degree of biculturalism. Besides, as Castro Paniagua (2000: 1-2) explains, the fact that a cultural feature is considered ideal in a given society does not necessarily mean that it will also be so in another. This is why "impartiality and objectivity may be difficult to achieve." To this I would add that this is possible not only between two different societies, but also among the different groups or subcultures that can make up a society, a fairly common phenomenon in highly 
multicultural societies. According to Castro Paniagua, the comparison among our different perceptions of the world often turns into a painful experience, particularly if we analyze our own society and discover certain areas that we would prefer to regard as nonexistent in our cultural system (as I see it, living abroad for a certain period of time is probably one of the best ways to put oneself in that position). In any case, as he also expresses, "Language is the reflection of a culture" (1). Thus, when we translate, we make "a cross-cultural comparison through a linguistic filter" and we compare "languages, cultures and societies."

These days the researchers who put the emphasis on the cultural aspects of translation are numerous, as Marco (2002: 203) reminds us, and I shall include myself on that list. Even historically linguistic approaches (such as Nord's and the German functionalism) conceive translation as an intercultural communication process involving two parts: on the one hand, the production of the source text in a source communicative situation and, on the other, the production of the target text in a target communicative situation (Nord 1991: 7). Regarding these two parts, it could be advisable to consider the respective receptions of each production, too.

Marco also draws our attention to the cultural turn that the Translation Studies discipline has undergone mainly from the 1980s (an irreversible tendency). ${ }^{1}$ He offers an overview of how that turn has developed, and from that summary I shall mention the following key points (2002: 203-205). First, from an anthropologic standpoint, Snell-Hornby (1988: 46) affirms that translation does not take place between languages but between cultures. Therefore, the translator must be not only bilingual, but also bicultural. Second, despite their linguistic orientation, authors such as Hatim and Mason (1990), Bell (1991), Baker (1992), and Neubert and Shreve (1992) make it clear

\footnotetext{
${ }^{1}$ See also Ortega's work (2007), which is devoted to the cultural turn and its influence on translation studies.
} 
118 Building Bridges Between Cultural Studies and Translation Studies

that the context in which texts are translated and received would remain incomplete without the consideration of the cultural factor. Third, Carbonell (1999) identifies the beginning of the cultural turn with the emergence of the manipulation school. According to Marco, this is somehow surprising, since the concept of culture is not the most prominent one within the polisystem paradigm's whole of postulates, especially if compared with the leading role of other notions such as description, target pole, system, and norm (despite the undeniable cultural approach that they all imply). Finally, Katan (1999) aims to give rigour and coherence to the study of the relationship between translation and culture.

From a descriptivist perspective, and in a similar line of reasoning, Toury (1995: 56) understands translation as an activity "which inevitably involves at least two languages and two cultural traditions, i.e., at least two sets of norm-systems on each level.” In an analogous manner, Hermans (1999: 89) suggests that "since translation operates in and on existing discourses while fashioning new texts after models belonging to other discourses, individual cultures or groups may develop different attitudes with regard to these potentially disruptive new arrivals.”

All in all, it seems clear that it is possible (and convenient) to consider translation from an intercultural perspective, which implies the confluence that cultural studies and translation studies experience at a given point ${ }^{2}$ (although I would probably not go as far as Lambert 1992: 18 when he claims that, given the impossibility of excluding the cultural component, whether we like it or not there is no such a thing as an ideal translation; as I see it, a translation's ideality is a relative notion).

Thus, the concept of culture appears as crucial to translation, and

\footnotetext{
${ }^{2}$ In this sense, see Herbrechter's 2002 work, which gathers a series of articles dealing with the concept of interdisciplinarity or the relationship between the two mentioned fields of study. On the other hand, no epistemological controversy is intended in this article.
} 
translation practice can be seen as a clear instance of interaction between cultures. Obviously, that interaction can be successful or unsuccessful; that is, (functionally speaking) a translation will be successful if the original purpose is achieved within the target context.

\section{The Translator as an Intercultural Expert}

If we agree that translation is an intercultural activity, the next logical step is to consider the translator's role within this approach. The contributions that lead to a conception of the translator as an intercultural expert or mediator are many. Snell-Hornby's work (1999), for example, pictures the translator as an expert in intercultural communication who performs his or her job in an internationalized world, which in its turn is characterized by the abundance of individual cultural communities.

Such approaches seem accurate, particularly if we conceive translation practice as an intercultural exchange. To support this position, I now refer to some statements made from diverse standpoints. Starting from their conception of the translation process as a communicative act, Mayoral et al. (1988: 357) perceive the figure of the translator as "a decoder of the source language as well as a encoder of the target language," being at the same time "a receptor of the message in the source culture as well as a source of the message in the target culture.” Here we can clearly see how both the source and the target cultures are taken into account to approach the (intercultural) communication process that every translation implies.

Similarly, and from a textual and discursive approach, Hatim and Mason (1990: 223-224) argue that the translator acts as a mediator not only in the sense that he or she "reads in order to produce" and "decodes in order to re-encode," but also in the sense that he or she 
120 Building Bridges Between Cultural Studies and Translation Studies

mediates (a key verb) between cultures, since he or she tries "to overcome those incompatibilities which stand in the way of transfer of meaning." That would be the reason why, together with his or her bilingual ability, a bicultural vision is crucial to the translator.

Toury (1995: 53) also favours the role of the translator as a cultural mediator. According to him, in spite of the "explanatory power with respect to translational phenomena" of disciplines such as Linguistics, Text-Linguistics, Contrastive Textology, and Pragmatics, "being a translator cannot be reduced to the mere generation of utterances which would be considered 'translations' within any of these disciplines." He adds that "Translation activities should rather be regarded as having cultural significance" and that "Consequently, 'translatorship' amounts first and foremost to being able to play a social role." In one word, not only does the translator play a communicative role, but also a social role.

Agost develops her theoretical framework from Hatim and Mason's model (1990). She mentions the high control that the translator must possess of the different sociocultural aspects surrounding the source language (1999: 100). Even if it seems obvious, we could add that the translator should also have control of the sociocultural aspects surrounding the target language, since on occasions we are not aware of certain features that shape our own culture.

Santamaria (2001a: 246) is another author who talks about the role of the translator as a cultural mediator. She suggests that when the references to be translated do not exist in the target culture, the translator must provide them with some symbolic value.

Castro Paniagua (2000: 24) goes further and proposes that "a translator should be an ethnographer." He considers that it is the translator's responsibility to interpret correctly not only the semantic information, but also the inherent cultural codes. In his opinion, "the translator must adequately transmit and adapt [the] message across cultures," so he or she "need[s] to have a deep knowledge of the 
cultural frames [he or she] will be handling.” Castro Paniagua also makes clear that a translator is not to be held blameworthy for a cultural sign that is not possible to be transcribed or for the lack of universality in a text. According to him, “A work's potentiality to achieve universal dimensions will rest upon the literary genius of a writer," and the translator's task will be to transmit it (24). In my view, it could also be argued that certain gaps in the receiver's previous knowledge of the world may be responsible for such lack of universality. In any case, this last idea stems from a pragmatic approach that is beyond the scope of this paper.

We can find similar approaches in other fields of study. For instance, let us consider Cateora and Graham's contribution. They devote their research to the analysis of international marketing. Still, in their work we can find several ideas that can be applicable to the issue at stake. For example, they (1999: 85-86) point out that "What a marketer is constantly dealing with is the culture of the people" and that "When a promotional message is written, symbols recognizable and meaningful to the [culture] must be used." Moreover, in a cultural context "The marketer's efforts are judged for acceptance, resistance, or rejection" of a given product. These ideas are clearly comparable to the world of translation in general and to the field of audiovisual translation in particular. As suggested earlier, the translator must study or at least have some knowledge not only of the source culture, but also of his or her own culture. Just as it can happen when marketing any other product, a translation's success or failure will be determined by acceptance or rejection (note that here we are considering any translated product a marketable product - a book, a film, a television series, etc.). In fact, an audience exposed to, for example, a television series the translation of which poses numerous cultural shortcomings could become an audience prone to end up ignoring that show.

Regarding language, Cateora and Graham (1999: 94) mention how important it is for the marketing expert to learn the language of 
the market in which he or she plans to do business. For obvious reasons, this is also applicable to the translator. They also claim that "Language may be one of the most difficult cultural elements to master," and suggest that on occasions it may be advisable to resort to a cultural translator ("a person who translates not only among languages but also among different ways of thinking and among different cultures;" this figure seems pertinent not only in the translation of written texts, but also - and maybe even more - in oral translation or interpreting). That way, obscene, offensive, or simply ridiculous results could be avoided. In a nutshell, they also advocate for the figure of the translator (or interpret) as a cultural expert or mediator.

\section{Culture and Audiovisual Translation}

Let us now turn our attention to some of the links between the cultural dimension and audiovisual translation. According to Delabastita, it is not possible to study audiovisual translation without considering the cultural contexts (1990: 105). Whitman (1992: 125) states that "Any film is a mirror of the culture in which it unfolds," a statement that seems applicable to other audiovisual genres (such as television situation comedies). She suggests that the translator cannot avoid facing some “'untranslatable' culturallyspecific content in a film." She also states that on certain occasions the translator will have to oberve suggestions or orders (in other words, a translation brief) 'from 'above' to alter other 'foreign' elements and culturally unfamiliar items to make them more attractive (that is, marketable) to the target language audience.” Hence, the question she asks is: how can these cultural features (including "Internalized moral values, shared political and historical identity, collective aesthetic tastes," all of them capable of becoming serious restrictions) be transferred in such a way that they remain 
intelligible (a priority) to an audience with a different cultural background?

Agost seems sensitive to this query in her model of analysis of dubbing. She (1999: 99-104) argues for a semiotic approach and mentions three main aspects: the cultural elements, intertextuality (I will deal with these two features next), and ideology (I will not discuss it, since it is out of the scope of this paper).

Goris (1993: 188) is also emphatic in the matter, and points out that the "fact that publications have focused on the technical aspects of 'how to produce (good) dubbing' rather than on the links between dubbing and the socio-cultural frame indicates that this new kind of media communication has yet to be integrated into the field of socio-cultural research.” Precisely, articles such as this one aim at contributing to diminish that shortcoming.

\subsection{Cultural References}

Let us consider now the question of the cultural references within the field of audiovisual translation. Agost's work ${ }^{3}$ seems attractive for its definition of cultural referent (1999: 99): specific places in a city or country; aspects related to history, the arts, and the customs of a society and of a given age (songs, literature, aesthetic concepts); celebrities; mythology; gastronomy; institutions; currency, weights, and measures; etc. In short, as she suggests, a cultural referent would be everything that makes a society have its own idiosyncrasy and be different from another. Her work is also significant because it does not ignore other important considerations. For example, she (1999: 100) refers to the way in which the context helps understand those references. On the other hand, it is also possible for the source and target cultures to share referents, a fact

\footnotetext{
${ }^{3}$ Molina's work (2006) is also of interest, since it includes a descriptive study on the translation of cultural referents.
} 
124 Building Bridges Between Cultural Studies and Translation Studies

that will help diminish the possible differences. Additionally, the cultural domination exerted by certain countries over others favours for many aspects of their culture to be well-known outside their frontiers, which in turn obviously helps facilitate the comprehension of this type of elements. ${ }^{4}$

An example of this last idea could be the case of the US. Many North American audiovisual products are shown on other countries' screens on a daily basis. Some of those cultures share many cultural features, especially because of the current dominant status - not only economical, but also cultural - of the former (keeping in mind that, as Cateora and Graham state, "The approach to life, values, and concepts of acceptable and unacceptable behavior may all have a common heritage and may appear superficially to be the same, yet in reality profound differences do exist” 1999: 104). Viewers from different countries come into contact (for example, via film or, mainly, via television) with a good deal of North American cultural references that are already shared or are in the process of being assimilated as a result of the globalisation process. Situation comedies are particularly relevant in this sense, since they offer a significant number of this type of elements. Some of them will cause no problem, but others will pose some serious trouble to the translator.

The work of Santamaria (2001a, 2001b, and 2001c) is of particular significance when considering the cultural referents within the scope of screen translation. ${ }^{5}$ Among her main hypothesis and conclusions we find the following ones. She (2001a: 237) defines cultural referents as the objects and events created within a given culture with a distinctive cultural capital which is intrinsic to the whole of the society and capable of modifying the expressive

\footnotetext{
${ }^{4}$ For a deeper discussion on the cultural contagion that takes place between cultures see Martínez-Sierra (2008a).

${ }^{5}$ She focuses on the English-Catalan translation of these elements.
} 
value that is given to the individuals who are related to it. This is a rather productive definition since, as she indicates, it allows us to identify different groups (microgroups) within a given society (it would seem rather simplistic to consider that all societies constitute homogeneous entities). The clothes, the music, and the social issues of interest act as factors that make it possible to identify the different groups.

Besides, starting from and adding precision to Nord's definition of cultureme (1997, for example), Santamaria (2001a: 238) talks about the association of culturemes with the problems a translation may cause. She also stresses the inclusion in any given analysis of the totality of cultural referents, and not just of those that may differ between the source and target cultures (2001a: 239). This is a sound indication, since too often the study of translation appears to be limited to the consideration of what changes and not of what remains unchanged. It seems rather reasonable to assume that if we are to map translation practice and look for regularities and norms, the whole picture should be considered.

One of her (2001a: 244) most interesting conclusions, which makes clear the relationship between the foreignization/domestication duality and the cultural referents, is that when subtitling into Spanish or Catalan the translation of those referents is usually foreignizing, whereas it is habitually domesticating when subtitling into English, a regularity that could be understood as a possible translation norm (or, at least, as a translation tendency - see Martínez-Sierra 2008b). ${ }^{6}$

Santamaria's analysis shows other remarkable data such as the fact that the higher the number of imported foreignizing elements, the greater it is the target culture's general knowledge about the

\footnotetext{
${ }^{6}$ There is a clear agreement on what a norm is. However, defining accurately when a recurring translation strategy stops being so and becomes a norm remains unsettled.
} 
126 Building Bridges Between Cultural Studies and Translation Studies

more specific characteristics of the source culture. In this sense, she argues that many foreign referents are introduced in the target culture's implicit knowledge (in its collective unconscious), and so the target individuals end up forgetting that these referents came initially from another culture (one more effect of the globalisation process) (2001a: 245-246).

According to her (2001b: 163), "Translators must be aware of the fact that viewers of dubbed or subtitled films will interpret cultural elements, that is, they will assign them expressive value from the referential value, according to the previous knowledge they have of any given cultural reference." In this sense, translators are (again) portrayed as intercultural mediators and experts.

Finally, Santamaria also speaks of priorities and argues that "when translating cultural references the priority must be to reflect a particular social reality in such a way that viewers can understand it through the usual cognitive processes” (2001b: 164). This is a quite accurate statement, although from a functionalist perspective it could be said that that would in fact be the priority should the translation brief consider it to be so. Otherwise that priority would occupy the position that the aforementioned brief assigned to it in the rank of preferences.

As we have seen, it is possible - and most likely useful - to deal with the question of the cultural referents from the perspective of priorities and also of restrictions. Regarding restrictions, Whitman (1992: 133) reflects on the explicit allusions and describes them as one of the most noticeable pitfalls. According to her, when the target audience is to face unfamiliar proper names, events, institutions, and the like and lacks the necessary background information to understand them, it does not make any sense to retain those referents since understanding would be sacrificed. She proposes as a plausible solution to render equivalents that trigger a similar response in both cultures. But she also explains that the lack of time or of imagination often force translators to resign themselves to keeping 
the unfamiliar names and "letting the audience either shrug their shoulders or elbow their neighbors with an accompanying, 'Huh?'”

However, we can find some other voices that suggest a slightly different - and probably more accurate - perception of the matter. In an e-conversation with Spanish professional translator María J. Aguirre, she pointed out that translators try to help adapters by explaining them who or where the referred person or place are. Similarly, she added, they suggest other names that might be more familiar to the target audience (in the case of humour, for example, this can be very useful to retain a gag). She expressed her conviction that it is not advisable to be too patronizing and to underestimate the viewer's comprehension potential and, consequently, to eliminate from the text all references to current people or places, which would turn the translated text into a pedestrian version of the original. Focusing on The Simpsons, one of the audiovisual products that her team translates for the Spanish market, Aguirre explained that she suggests a replacement of the many cultural referents that this series has only when they refer to very local entities or facts that most target viewers do not know. ${ }^{7}$ Additionally, and this is particularly important with regard to the foreignization/domestication duality, Aguirre clearly showed her determination to never substitute those elements for specific target references (another question will be if the dubbing director, for example, respects or not that determination).

In any case, we could think about what is worse: to leave an explicit reference unaltered or to substitute it for another that could seem artificial and out of place (of course, there would be a clear subjective factor here). ${ }^{8}$ Maybe the answer lies in finding a halfway solution. But it will not be here where that solution is supported

\footnotetext{
${ }^{7}$ The question could be asked how can that lack of knowledge be assessed? Marco (2002) proposes a list of some of the ways in which the intertextual elements - and the cultural referents as well, I would say - can be relevant for the literary - and audiovisual, I would also say - translator .

${ }^{8}$ For a deeper discussion of these two possibilities, see Martínez-Sierra 2006.
} 
128 Building Bridges Between Cultural Studies and Translation Studies

since, as Zabalbeascoa suggests, "Priorities and restrictions will have to be fixed anew for each task," (1997: 331) paying attention to the translation brief's instructions.

Finally, Lorenzo et al. (2003: 282-283) allude to another restriction that seems worth mentioning. According to them, "We must bear in mind that the choice of a referent grounded in a particular historical context will only work, i.e., be recognized and accepted by both source and target audiences, for a limited period of time." They also say that that referent will "eventually [require] further modifications in the future" and that if a given "series was to be shown again at some point in the future, the possibility of replacing [this kind of references] should be considered.” There is logic behind this statement, but it suggests a scenario that unfortunately seems rather unrealistic and impractical, since it would imply the redubbing or resubtitling of a great number of episodes (if talking of a TV series) every given period of time. Moreover, if we made it applicable to other products, films would also have to be redubbed or resubtitled and even books would have to be rewritten, just for the same reason. In any case, it does seem pertinent to draw attention to the cultural dynamism that makes cultures constantly evolve and periodically refresh their inventory of cultural elements.

\subsection{Intertextual References}

Intertextuality can basically be described as the way in which we relate texts between them from our previous textual experience, which is part of our previous knowledge of the world. However, within the field of translation, we see that it is possible to fine-tune the concept. Out of the five dimensions that Marco (2002: 268-270) distinguishes in the relationship between intertextuality and translation, I wish to focus on the first one he mentions: the allusion or reference to another text. As he suggests (1998: 186), it is a type 
of allusion the effect of which will depend upon the reader, though I would not say that exclusively, since the mediation of the translator can certainly affect the process. In any case, I would agree that the receiver's previous textual experience will be the one to eventually allow him or her to decode it or, at least, to identify it.

Regarding the consideration of intertextuality within the field of audiovisual translation and, more particularly, within the dubbing practice, Agost's comments seem relevant. She puts forward a suitable definition of the concept, as she claims that in an audiovisual text intertextuality can be defined as the presence in that same text of references to other texts (oral, written, or - I would add - audiovisual), be them current or previous (1998: 220). It is a definition that is as simple as it is practical.

Concerning the role of the translator when dealing with this type of references, I agree with Agost (1998: 220) when she argues that the translator must be able to spot any intertextual element and to translate it accordingly, so that the target and the source audiences can meet the same conditions to detect those elements (provided that the necessary background knowledge is present). In other words, she (1999: 103) explains that these textual occurrences constitute signs that the receiver must be able to interpret to achieve a total comprehension of the meaning. Hence, the translator must be capable of identifying this type of reference and of rendering the best solution possible so that the target viewer can have access to that intertextuality (mostly if we consider them a translation universal, just as Lorenzo 2005 does). Once again, as it already happened in the case of the cultural referents, the consideration of the translator as an intercultural expert or mediator seems appropriate.

Lorenzo et al. (2003: 283) also touch upon this subject. They understand that "Intertextual references usually give rise to many translation problems." According to them, "The translator must spot the reference in the first place, and then evaluate [on an intuitive 
130 Building Bridges Between Cultural Studies and Translation Studies

basis, depending on the 'general knowledge' of the translator and the target audience] the likelihood of it being recognized by the target audience.” That way he or she will be able to opt for the best solution possible, which is not always an easy task. I agree with their claims and also with Agost (1998: 220) when she argues that (as it is obvious) the viewer must be capable of decoding these references in order to understand the entire meaning of the text.

Another factor to be taken into account is the type of audiovisual genre. Let us consider for example the case of televised animated cartoons, where the type of recipient has a significant effect on the question of - among others - intertextuality. Most cartoons are meant for children and have entertainment as their major goal. Thus, they usually display some intertextuality free contents, as Agost (1998: 226) explains. A totally different issue would be cartoons geared toward adults; in television shows such as The Simpsons or Family Guy intertextuality is vastly present and, in fact, determines a high percentage of the humor. Similarly, Zabalbeascoa (2000: 20) thinks that the children's genre could be expected to be characterized by a degree of intertextuality notably inferior when compared to that of those texts typically considered as adult-oriented. One further case would be those cartoons that attract both children and adults. Regarding this last type of cartoons, he (2000: 21) talks about texts that make use of a black-spots-over-white-background strategy; in other words, allegedly children's texts (the white background) containing certain elements (the black spots, i.e. cultural or intertextual references) specifically intended for adult amusement.

Agost pays attention to the problems (or restrictions) that intertextuality can cause in the translation stage of the dubbing process (many of her words could also be applicable to the case of subtitling). She refers to famous quotes, which usually already have a corresponding famous translation. Translators find themselves in the position of trying to provide that famous translation of the quote while at the same time dealing with the characteristic restrictions of 
dubbing (mainly, those that have to do with visual synchrony). We have to take into account that, in the case of famous texts, many people know them, which might cause the translator to find him or herself in the middle of a crossroads: either to offer a translation that can be recognized by the target viewers or to pay attention to those limitations that the visual restrictions may pose (1998: 226, 228). A further problem could arise if the translator lacks the necessary previous knowledge that allows him or her (first) to detect the presence of the reference in question in the source text and (second) to employ the coined target translation.

It is true that, as Agost explains, intertextuality is often easy to detect, as it can happen in the case of titles of books or songs, for example. But on other occasions it hides behind clichés, literary allusions, famous proverbs, or idioms (especially if some linguistic alteration is present). In these cases, the techniques and strategies available to the translator are many (addition, adaptation, elimination, and other similar ones) (1998: 241).

According to Agost, along with the excellent cultural background that the translator should posses, there are other factors (or restrictions) that have an influence on the final translation and that should be borne in mind: (1) the professional aspects (such as the initiator's translation brief), (2) the receiver's competence and expectations, (3) the interaction among the dimensions of context (pragmatic, semiotic, and communicative), and (4) the synchrony, which can cause the form and even the content of a text to have a secondary role. In short, linguistic and cultural competence, creativity (in the sense of wit), the search for necessary information, and a skilful control of the synchrony techniques are key elements in the appropriate translation of intertextuality (1998: 241), and clearly stand out among the skills that translation trainees should develop.

Lastly, audiovisual translation deals with a certain type of text (audiovisual). Therefore, when considering the question of intertextuality we should not ignore that it is a phenomenon that will be affected by 
the nature of the text in which it occurs. That is, when considering those factors that are specific to an audiovisual text it is also possible to talk about the resources that this type of text has to create intertextuality. Thus, we cannot ignore that voices (imitations, characteristic ways of speaking, etc.) can create intertextuality, just as it happens with images (and sounds, I should add), which can also be the source of intertextual references, as Zabalbeascoa (2000: 26) explains. The idea that visual and acoustic elements can act as vehicles of intertextual (and cultural) references seems crucial, and makes it possible, in my opinion, to talk of audiovisual intertextuality.

\section{Conclusions}

As we have seen, bridges between Cultural Studies and Translation Studies are not just a possibility but a fact. My purpose was not to present any groundbreaking approach to the way translation practice can be understood and studied, but rather to review and recapitulate some of the voices that - from different, yet related fields - lead to an intercultural conception of what translating means.

Additionally, the translator has been described as an intercultural expert or mediator working in a globalised environment. This perception is crucial not only in actual practice, but also in the training of future translators and even interpreters. Bilingual and bicultural abilities seem equally important, and target culture knowledge should not be taken for granted but should also receive its share of attention.

Finally, I have focused on the audiovisual field to reflect on the importance of cultural referents and intertextual allusions. We have seen some of the problems they may cause due to their restrictive nature. Shared and background knowledge has been portrayed as key in dealing with this type of elements, which again take us to the notion of the translator not only as a fine bilingual professional, but 
also as an effective bicultural agent.

\section{References}

Agost, R. 1998. Traducció i intertextualitat: el cas del doblatge. In Ll. Meseguer \& M. L. Villanueva (eds.), Intertextualitat $i$ recepció 219-243. Castellón de la Plana: Universitat Jaume I.

_. 1999. Traducción y doblaje: palabras, voces e imágenes. Barcelona: Ariel.

Baker, M. 1992. In Other Words: A Coursebook on Translation. London: Routledge.

Bell, R. T. 1991. Translation and Translating: Theory and Practice. London: Longman.

Carbonell, O. 1999. Traducción y cultura: de la ideología al texto. Salamanca: Ediciones Colegio de España.

Castro Paniagua, F. 2000. English-Spanish Translation, Through a Cross-Cultural Interpretation Approach. New York: University Press of America.

Cateora, P. \& J. Graham. 1999. International Marketing. Madrid: Irwin McGraw-Hill.

Delabastita, D. 1990. Translation and the Mass Media. In S. Bassnett \& A. Lefevere (eds.), Translation, History and Culture 97-109. New York: Pinter.

Goris, O. 1993. The Question of French Dubbing: Towards a Frame for Systematic Investigation. Target 55.2, 169-190.

Hatim, B. \& I. Mason. 1990. Discourse and the Translator. London: Longman.

Herbrechter, S. (ed.) 2002. Interdisciplinarity and Translation. New York: Rodopi.

Hermans, T. 1999. Translation in Systems. Descriptive and Systemoriented Approaches Explained. Manchester: St. Jerome.

Katan, D. 1999. Translating Cultures. An Introduction for Translators, 
134 Building Bridges Between Cultural Studies and Translation Studies

Interpreters and Mediators. Manchester: St. Jerome.

Lambert, J. 1992. The cultural component reconsidered. In M. Snell-

Hornby et al. (eds.), Translation Studies. An Interdiscipline 1726. Philadelphia: John Benjamins.

Lorenzo, L. 2005. Funcións básicas das referencias intertextuais e o seu tratamento na traducción audiovisual. Quaderns: revista de traducció 12, 133-150.

Lorenzo, L., A. Pereira \& M. Xoubanova. 2003. The Simpsons / Los

Simpson. Analysis of an Audiovisual Translation. The Translator 9.2, 269-291.

Marco, J. 1998. Intertextualitat i traducció: les línies bàsiques d'una relació inevitable. In L. Meseguer \& M. Villanueva (eds.), Intertextualitat i recepció 185-189. Castellón de la Plana: Universitat Jaume I.

. 2002. El fil d'Ariadna. Anàlisi estilística i traducció literaria. Vic: Eumo.

Martínez-Sierra, J. 2006. La manipulación del texto: sobre la dualidad extranjerización / familiarización en la traducción del humor en textos audiovisuales. Sendebar 17, 219-231.

. 2008a. The Contact between Cultures and the Role of Translation and the Mass Media. Translation Journal 12.1.

. 2008b. Humor y traducción. Los Simpsons cruzan la frontera. Castellón: Universitat Jaume I.

Mayoral, R., D. Kelly \& N. Gallardo. 1988. Concept of Constrained Translation. Non-linguistic Perspectives of Translation. Meta 33.3, 356-367.

Molina, L. 2006. El otoño del pingüino. Castellón: Universitat Jaume I.

Neubert, A. \& G. Shreve. 1992. Translation as Text. Kent (Ohio): The Kent State University Press.

Nida, E. 1964. Toward a Science of Translating. With Special Reference to Principles and Procedures Involved in Bible Translating. Leiden: Brill. 
Nord, Ch. 1991. Text Analysis in Translation. Amsterdam: Rodopi. . 1997. Translating as a Purposeful Activity. Manchester: St. Jerome.

Ortega, E. (ed.) 2007. El Giro Cultural de la Traducción. Reflexiones teóricas y aplicaciones didácticas. Frankfurt: Peter Lang.

Samovar, L. \& R. Porter (eds.) 1997. Intercultural Communi-cation. New York: Wadsworth / Peter Lang.

Santamaria, L. 2001a. Función y traducción de los referentes culturales en subtitulación. In L. Lorenzo et al. (eds.), Traducción subordinada (II): El subtitulado 237-248. Vigo: Universidad de Vigo.

. 2001b. Culture and Translation. The Referential and Expressive Value of Cultural References. In R. Agost \& F. Chaume (eds.), La traducción en los medios audiovisuales 159-164. Castellón de la Plana: Universitat Jaume I.

. 2001c. Les referències culturals: aportació informativa i valor expressiu. El subtitulat. Doctoral Dissertation. Barcelona: Facultat de Traductors i Intèrprets de la Universitat Autònoma de Barcelona.

Snell-Hornby, M. 1988. Translation Studies. An Integrated Approach. Philadelphia: John Benjamins.

. 1999. Communicating in the Global Village: On Language, Translation and Cultural Identity. Current Issues in Language and Society 6.2, 103-120.

Toury, G. 1995. Descriptive Translation Studies and Beyond. Philadelphia: John Benjamins.

Whitman, C. 1992. Through the Dubbing Glass. New York: Peter Lang.

Zabalbeascoa, P. 1997. Dubbing and the nonverbal dimension of translation. In F. Poyatos (ed.), Nonverbal Communication and Translation 327-342. Amsterdam: John Benjamins.

. 2000. Contenidos para adultos en el género infantil: el caso del 
136 Building Bridges Between Cultural Studies and Translation Studies

doblaje de Walt Disney. In V. Ruzicka et al. (eds.), Literatura infantil y juvenil: tendencias actuales en investigación 19-30. Vigo: Universidad de Vigo.

Juan José Martínez-Sierra

Departamento de Traducción e Interpretación, Universidad de Murcia 30100 Murcia, Spain

Phone: +34 868 883000; Email: sierra@um.es

Received in Jan, 2010; Reviewed in Feb, 2010; Revised version received in Mar, 2010 